\title{
Consumer Buying Behavior of Gold \&Gold Jewellery of Nagpur Region
}

\author{
${ }^{1}$ Sumit G. Khadekar\& ${ }^{2}$ Dr. Ramesh R. Kohad \\ ${ }^{I}$ Department of Business Management, RTM Nagpur University, Nagpur,India. \\ ${ }^{2}$ Department of Commerce, S.S.N.J.Mahavidyalaya, Deoli, Distt- Wardha,India.
}

\begin{abstract}
This paper deals with the consumer Buying Behavior is known. The consumer selected to study is in Nagpur Regions. The Respondent both from Nagpur Rural \& Urban Area including Jeweller's\& final consumer's both.The research will show that why consumer buy gold, How they buy, When they buy most. their future, purpose about gold. The investment view of consumer also studied in research. We areknow about gold but not in detail. Some scientific and important introduction of gold as well as carat system also discussed.
\end{abstract}

\section{Introduction}

Gold is precious metal. every one know about gold value. In India other than remaining Nation, The craze for gold is much more. In India from Ancient from Birth to death the gold is used in many eventsof life. The Business of gold \& gold Jewellery selling \& buying is not new.The attraction toward gold \& gold Jewellery also increases day by day. The rate of gold also increased. In few years consumer's buying behavior of gold \& gold Jewelleryincreased. From many years the gold Business sector is handled by traditionalJeweller's But in last 10-15 year's , many companies are entered in these sector.As per the change in time the look out of consumer and their preferences toward Buying gold Jewelley also change so it is much more beneficial to study the consumer Buying Behavior of gold \& gold Jeweller

The gold jewellery is the main attraction of women. However which describe why ladies having gold jewellery more.

1. Sentimental value.

2. To feel good about self

3. Exposes Individuality.

4. Modern \& up-to-date

5. Be cool \& Trendy

6. Make a firstimpression

7. Look professional at work

8. Make a good impression on opposite sex.

9. Be admiral \&suspected.

10. Displaywealth\& status.(National jewelersmagazine)

In Jewellerytheir are so many items some of them are ear Tops, earrings, rings, Necklaces, bracelets, Bangles, Mangalsutra (The symbol of Marriage life.) etc. [2]

As like other product buying By the consumer's, In the gold \& gold jewellery Buying process there are many factor which effect the buying Behavior of customer.

(1) Tradition

(2) Ornaments for occasion

(3) Price / Investment

(4) Status symbol

(5) Necessity

As per the survey of 200-300customer. It is describe the $65 \%$ of Jewellery is planned purchase, while the reaming $35 \%$ is the impulse purchase.In planned purchase gold Jewellerythere is 'price' which is factor affect most to which item is to buy. Consumer Buying Behavior in Jewellery industry can be studied on the internal parameters. such as price, occasions like, Festivals, Birthday, Anniversary, Marriage, Engagement etc. Consumer faith on Traditional Jewellers to buy gold Jewellery or Branded Jewellers. Their offer's Exhibitions, Advertises, Awareness also affect consumer most.

\section{Scientific Characteristics of Gold}

(1) The chemical symbol for gold is Au.

(2) Gold atomic number is 79 and it's atomic weight is 196.967 
(3) Gold melt of 1064.43 Centigrade

(4) The specific gravity of gold is 19.3 , meaning gold weight 19.3 times more than an equal Volume of water.

Table:1 Carat System of Gold

\begin{tabular}{|l|l|l|}
\hline$\%$ of gold & European pattern & Carat System \\
\hline $100 \%$ & 1000 fine & 24 Carat \\
\hline $91.7 \%$ & 917 fine & 22 Carat \\
\hline $75.0 \%$ & 750 fine & 18 Carat \\
\hline $58.5 \%$ & 585 fine & 14 Carat \\
\hline $41.6 \%$ & 416 fine & 10 Carat \\
\hline
\end{tabular}

(History of gold, National mining Association. 101 constitution Avenue, NW, Suite 500 East, Washington, DC- 20001) [4].

\section{Review of Literature}

The Indian market was witnessing a rapid shift of screening simple jewellery from investment to artistic appearing ornaments. Consumer having the latest new fashionable designs. The Indian consumer was willing to experiment with new design.

Study released by Bellion Association of India (2007) started that due to changingdynamics' traditional Jewellers are looking to jump on the bandwagon by the investing in Advertising and trying to build a presence in the minds of consumers. Traditional Jewellery have signed up Bollywood heroines, promotional others, gift, huge range of latest designs of Jewellery.

Gidwanidevika (2002) in her paper titled "Branded gold Jewellery Market in India" mentioned that there is definitely a market for branded Jewellery especially if something is aimed at the younger generation, which owns to buy fashionableJewellery. This is the real time to get into the market, as it has just started to take off :

According to economist Keynes (1936/1958), there are 8 motives behind savings. All the people do not have same motive and intensity. motive also varies from individual to individual. The precautionary saving motive is one of the oldest theories to explain savings. The Basic idea is that house holds save to smooth future consumption when faced with income uncertainty (Fried man, 1957).

\section{Research Methodology}

1) Sample area :- $\quad$ Nagpur District .

2) Data and source of data :- $\quad$ The study Based on secondary \& primary data. Secondary data from Journal,Magazine,Articles,Books\&Websites etc.Primary data obtain by survey through questionnaire.

3) Period of Study :- $\quad$ The period of study cover 5 years.

4) Data Analysis :- Data collected through primary \& secondary sources. Analysis of data done by using statistical techniques.

III. Data Analysis and Interpretation

Table:-2 Selling of gold\& gold Jewellery in 5 years in Nagpur region Market.

\begin{tabular}{|l|l|l|l|}
\hline Sr. No. & Year & In Tone & Growth Rate $(\%)$ \\
\hline 1. & $2010-2011$ & 5 & 2 \\
\hline 2 & $2011-2012$ & 7 & 2 \\
\hline 3. & $2012-2013$ & 8 & 1 \\
\hline 4. & $2013-2014$ & 5 & 3 \\
\hline 5. & $2014-2015$ & 4 & 1 \\
\hline
\end{tabular}

Graph 1:-Selling of gold\& gold Jewellery in last 5 years in Nagpur District Market.

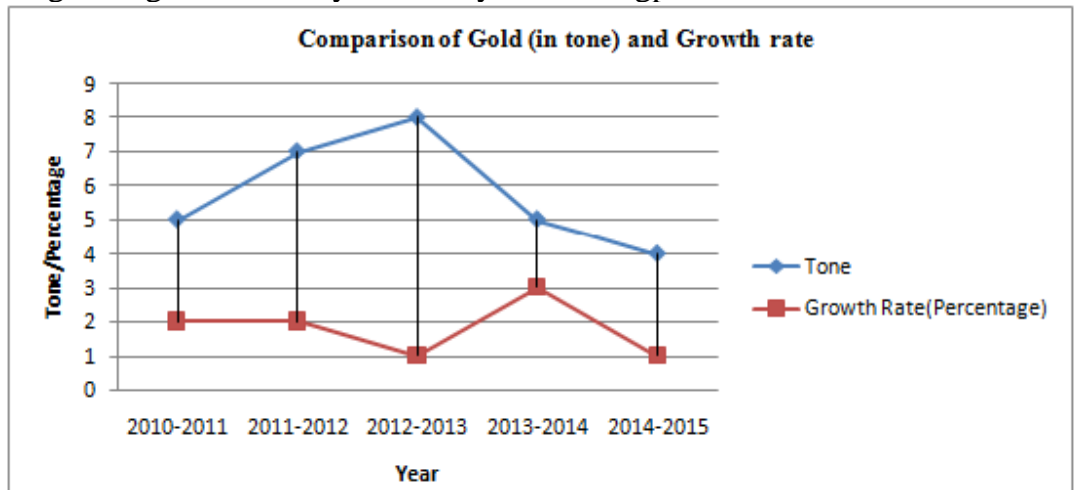


Table 3:-Comparison between rural \& urban people to buy gold \& gold Jewellery.

\begin{tabular}{|l|l|l|l|}
\hline Sr. No. & Year & Urban sale(tones) & \multicolumn{1}{c|}{ Rural sale(tones) } \\
\hline 1. & $2010-2011$ & 2 & 3 \\
\hline 2 & $2011-2012$ & 3 & 4 \\
\hline 3. & $2012-2013$ & 3 & 5 \\
\hline 4. & $2013-2014$ & 1.5 & 3.5 \\
\hline 5. & $2014-2015$ & 1 & 3 \\
\hline
\end{tabular}

Graph 3:-Comparison between rural \& urban people to buygold \& gold Jewellery.

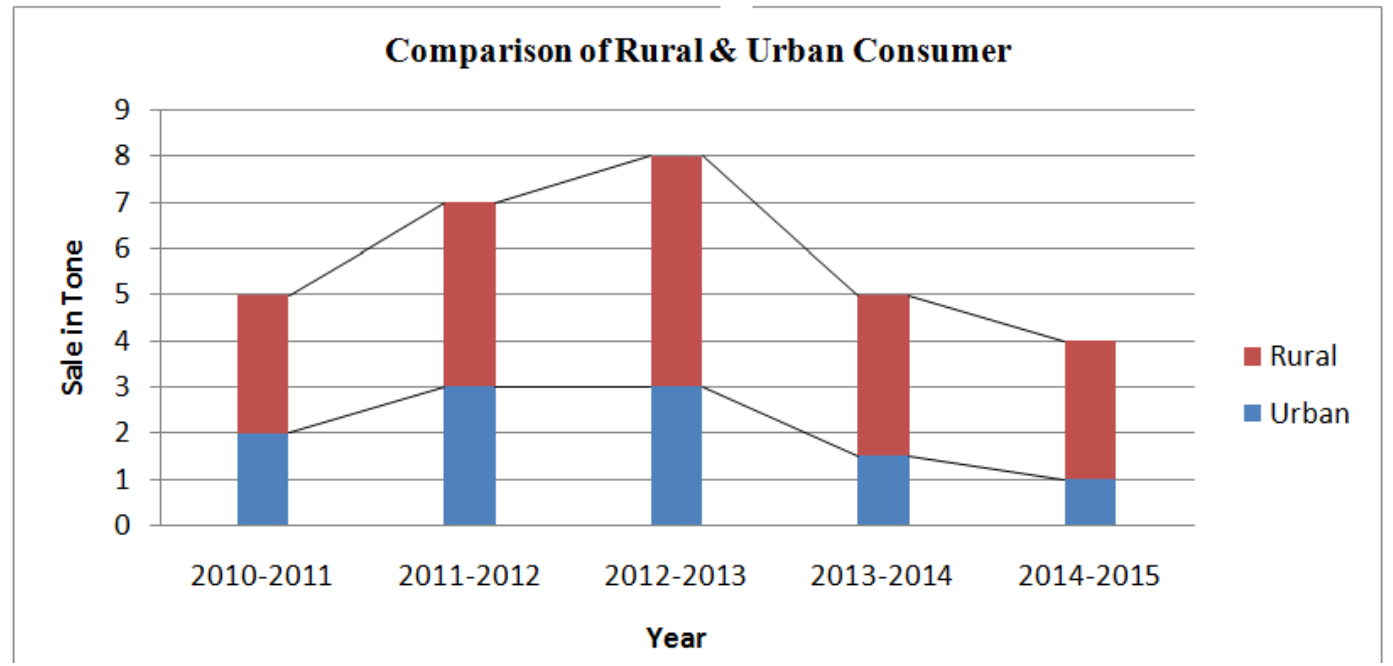

Findings

1) The sale of gold \& gold jewellery in Nagpur Region from 2010 to 2013 continuously increased but after that in some amount sale decreased. The highest sale of gold \& gold jewellery in 2012-2013 is 8 tones.

2) The growth rate of this sector in Nagpur District in 2012 to 2013 is very good, But after it is decline.

3) AAverage demand for gold \& gold jewellery of rural customer is more than urban area. But after 20122013 the position is different and demand of rural consumer is down year after year as compare to Urban consumer.

\section{Conclusion}

Consumer observestoward gold as pure investment.from last few years tremendousgrowth happened in this sector in Nagpur area.It provide earning opportunity to many people of this sector.New companies also entered in this sector, It provide jobs \& opportunity to new one.

From last three year the rural consumer demand less than Urban Consumer. Their is one important reason behind that the financial disturbance. The rural Area people are most of the Agriculture based and from last three years they are suffer from drought (dearth).For well development of this gold \& gold jewellery sector, government have to provide facilities \& benefits. (like loan, craftsman certificate course, Hallmark labs, Metal detector labs, gems testing labs, etc.

Books

\section{References}

[1] Dr. Michael V.P, Himalaya publishing,edition : 2008, Research methodology in management.

[2] Dr.Nirujain (Thesis),Consumer buying behavior with regard to branded \& traditional jewellery with special reference to Jaipur jewellery market.

[3] A.senthilraghavan\& Dr. N. nisarahamad, IJEIMS,vol-2,no-2,july-dec-2011, Passion for ornamental gold jewellery in india.

[4] National mining Association. 101 constitution Avenue, NW, Suite 500East,Washington, DC- 20001, History of gold.

[5] Biplas. S. Bose. Himalaya publishing House, Marketing Management.

Websites

[1] www.timesofindia.com

[2] www. gold.org/value/market intelligence/supply\&demand/jewellery. 